\title{
Teachers' Perception on the Implementation of Dual Language Programme (DLP) in Urban Schools
}

\author{
Nadiah Binti Has Bullah ${ }^{1} \&$ Melor Md Yunus ${ }^{1}$ \\ ${ }^{1}$ Faculty of Education, Universiti Kebangsaan Malaysia, Selangor, Malaysia \\ Correspondence: Nadiah Binti Has Bullah, Faculty of Education, Universiti Kebangsaan Malaysia, Selangor, \\ Malaysia. E-mail: nadiahhasbullah@gmail.com
}

Received: November 6, 2018

doi:10.5539/ass.v15n1p24
Accepted: December 1, 2018 Online Published: December 28, 2018

URL: https://doi.org/10.5539/ass.v15n1p24

\begin{abstract}
Today, English Language has become the language of communication in every area which includes economics, politics, technologies as well as education. It also has been placed as a second language in Malaysia due to its importance. Dual language programme (DLP) has been introduced and implemented in selected school since 2016 as an initiative programme to give the pupils the opportunity to use English Language in learning Science and Mathematics. It aimed to produce proficient pupils in the international lingua franca language. Thus, this study was conducted to examine the teachers' perceptions towards the implementation of DLP and to identify the factors that affect the implementation of DLP in urban schools. English, Science and Mathematics teachers from urban schools that implemented DLP were selected as respondents for this study. In order to achieve the objectives of this study, a set of questionnaire was developed and interview session were conducted to gather their point of view. Data was analysed using descriptive analysis. The results from the questionnaires and interview were presented in tables and figures and showed that the teachers have positive perceptions towards the implementation of DLP. However, there were some challenges faced by the teachers such as lack of teaching resources and facilities. This study's result aspires the ministry and DLP teachers to discover the possible solution to improve the implementing the programme.
\end{abstract}

Keywords: Dual language programme (DLP), teachers, perceptions, factors

\section{Introduction}

English language has become an important language used widely in the world. It plays an important role as a lingua franca in education worldwide. In Malaysia, English has been placed as the second language due to its importance in education, politics, economics and technologies (Thirusanku \& Melor, 2012). Government specifically the Ministry of Education (MOE) is emphasizing the importance of acquiring the language in the educational policy and planning. Many programmes have been implemented and changes were made in the educational policy as to provide opportunities for the pupils to learn and use the language as well as to strengthen their proficiency level.

In January 2003, MOE had reformed the education system by implementing teaching of Science and Mathematics in English (PPSMI) in all Malaysian school. The aims were to promote the use of English language among the Malaysian pupils and proficiency as well as to accelerate their mastery in Science and Mathematics. However, due to the sudden implementation of PPSMI, some controversies were arise. Teachers' acceptance, teachers' skills and knowledge, and pupils' performance and societies' acceptance were debated for years Melor and Saiful Islam (2017). Many studies show that PPSMI was unable to meet the objectives of the implementation of PPSMI which the proficiency level of the Malaysian pupils did not show improvement and they were also facing difficulties in understanding the Science and Mathematics subjects especially pupils in the rural schools (Mohandas, 2009; Jalaluddin, 2009; Haron et al., 2008). This happened because the pupils and the teachers were not proficient with the language well which lead to confusion in the teaching and learning session in the classroom. After discussing the advantages and disadvantages of the PPSMI, Tan Sri Muhyiddin Yassin, the former Minister of Education announced the abolishment of PPSMI using the 'soft-landing approach' starting 2012.

Besides PPSMI, Malaysian Education Blueprint 2013-2025 (MEB) is a result from transformation made by the government to ensure the education system continues relevant and raising the education standard internationally 
as to meet the challenges of the globalisation. Within the 11 shifts stated in the MEB to transform the education system, Shift 2 was focus on ensuring every child is proficient in Bahasa Malaysia and English Language and it is encouraged to learn additional language (Ministry of Education, 2013). Dual language programme (DLP) is an initiative programme under the Empowering Bahasa Malaysia and Strengthening English (MBMMBI) policy and the implementation of this programme was announced by the former Prime Minister, Datuk Seri Najib Razak in October 2015.

The implementation of this programme since January 2016 is in alignment with one of the goals in the Malaysian Education Blueprint 2013 - 2025 which aspires the pupils to be proficient in bilingual language; Malay language and English language. Through this programme, the pupils are given opportunity to use either Malay language or English language in learning Science, Mathematics, Information Technology and Communication, and Design and Technology subjects in classrooms. The objectives of the programme are to enable pupils to have access and explore wide range of knowledge in order to compete globally, to boost their English proficiency and to enhance pupils' future employability opportunities (MOE, 2015).

There are 1,214 out of 10,154 primary and secondary schools implementing DLP since January 2017 and the number of schools applying for DLP will be increasing in future (Menon, 2016). The implementation of DLP is upon the schools' request and the fulfilment of the four conditions which contrary with the implementation of PPSMI. The four conditions that the schools must fulfil are the school should have sufficient resources such as textbooks and teaching aids, the headmaster and the teachers are willingly to implement DLP, parents' support and request and the schools must ensure that their performance in Malay subject is achieved the average target or better than the national average grade.

The implementation of DLP since January 2016 had been debated for its similarity with PPSMI. Gerakan Pemansuhan PPSMI expressed their dissatisfaction over DLP which claimed to be similar with the PPSMI which have already recognised its failure through a series of studies and reports (The Star, 2016). Besides that, the issues raised since the implementation of DLP is the sudden implementation and teachers' readiness to conduct the teaching and learning session the subjects in English. The time frame given to the schools to prepare themselves was very short period and the sudden reformation may have undesired result due to lack understanding about DLP and readiness among the teachers. Regardless of the challenges faced by the teacher due to sudden implementation, Parent Action Group for Education Malaysia (PAGE) agreed with the implementation of DLP. In addition, the parents hope that the programmes will be expand to more schools in future (The Star, 2017).

The context of this study was focusing on teachers who are teaching Mathematics and Science in English under dual language programme in urban primary schools. This article discusses the challenges faced by the teacher when implementing DLP as they were given short notice to implement the programme and the factors affecting the implementation of the programme from the teacher point of view. It was hoped that this article could be beneficial to the policy makers to make improvement towards the programme. Besides that, this article can be a starting point and reference for other researchers as DLP is a new programme in Malaysia.

\subsection{Literature Review}

Dual Language Programme (DLP) also known as bilingual education or two way immersion programme refer to academic programme where it uses two languages; English language and the native language of certain community (Lindholm-Leary, 2001). The main idea of this programme is to ensure the pupils become proficient in English as well as their native language and each country implement this programme differently to serve their demographic context. This programme has been initiated in Florida since 1962 to fulfil the need of the non-English speaker as well as to preserve their culture who attends the public schools. In Malaysia, this programme involves Bahasa Malaysia and English language, where English language is used as medium of instructions in teaching and learning Mathematics and Science, whereby Bahasa Malaysia is used in teaching and learning subjects for selected schools only.

A research done by Collier \& Thomas (2004) in the United States schools conclude that the implementation of DLP benefits the pupils and gained supports from the parents, teachers and administrators. The programme is also successfully implemented because the stakeholders monitors and make improvement for the programme. This shows that involvement of the stakeholders viewing the programme and make betterment will benefits the pupils in academic performance.

Implementation of DLP in Malaysia is the reverted programme after the abolishment of Teaching Mathematics and Science in English (PPSMI) in 2012 (Melor \& Saiful Islam, 2017). The concept of the DLP is similar to PPSMI whereby English is the medium of instructions of teaching Mathematics and Science. The differences are 
the resources and the selection of the pupils where for DLP the schools and the pupils are given option either to use English or Bahasa Malaysia during teaching and learning Mathematics and Science as for PPSMI it was compulsory for all Malaysian pupils to use English as the medium of instructions for both subjects. The abolishment of PPSMI was done due to the reports and studies state some factors affect the failure of PPSMI. One of the factors is the teachers' readiness, skills and knowledge. Studies show that teachers' competency and readiness to teach Mathematics and Science in English was the main factors that affect the failure of PPSMI (Hamzah et al., 2009; Lim \& Chew, 2007; Hamidah et al., 2005). Many teachers agreed that they were not fluent and competent in delivering the lesson using English and prefer to use Bahasa Malaysia in the teaching and learning session in class. Hence, the pupils could not understand the language as well as the content of the lesson which affect the pupils' performance in academic. However, Ministry of Education assure that the teachers are ready and competent in implementing DLP because they already had experience in teaching Mathematics and Science during PPSMI and also the schools need to fulfil one of the criteria; teachers' willingness before applying for DLP. Teachers were also expected able to teach the subjects in English as the young teachers were the product of PPSMI few years back (Malaysian Digest, 2016). This is because, teacher had been exposed to the teaching Mathematics and Science in English during the implementation of PPSMI.

\subsection{Objective}

The objectives of this study are to examine teachers' perceptions towards the implementation of DLP in urban primary schools and also identify the factors that affect its implementation.

\section{Method}

\subsection{Research Design}

This study employed a survey design in which researcher collected both quantitative (questionnaire) and qualitative (interview) data in order to examine the teachers' perceptions towards the implementation of DLP in urban primary schools and also identify the factors that affect its implementation. By employing survey design for this study, the researcher can manipulate the data to answer the research questions in many ways and the data can be collected quickly (Piaw, 2016).

\subsection{Respondents}

This study was carried out in Wilayah Persekutuan Kuala Lumpur with selected schools implementing DLP. There are eight schools chosen to be the sample in this study. The respondent of this study were consists 22 teachers teaching Mathematics and Science in DLP classes at primary schools in Kuala Lumpur.

\subsection{Instruments}

The questionnaire items were adapted from the studies Kamlun (2005) and Ministry of Education (2002) with some modifications as to meet the objectives of this study. The questionnaire consisted of two sections: 1) demographic background and 2) their perceptions on their skills and knowledge. The first section contained 14 items about the teachers' background and teaching experiences. The second section contained 24 items about their skills and knowledge as well as the challenges that they faced in implementing DLP. The second section was made up of 23 items using 5-point Likert scale and 1 open- ended item. The open-ended item was purposely created to ask the teachers' suggestion in improving the programme.

Besides that, this study also utilised a set of semi-structured questions for interview. This interview questions is to obtain more understanding on the Mathematics and Science teachers' perception about the implementation of DLP. It is mainly used for the triangulation purpose.

\subsection{Data Collection Procedures and Analysis}

The data from questionnaire were collected via online by using Google form. The interview session was conducted face-to-face with the selected respondents and English teachers. The teachers were selected based on the purposive sampling and were asked based on the questionnaire questions as to gather better understanding on their perceptions towards the DLP programme. All the data from questionnaire were analysed by using frequency and percentage, whereby the open-ended item and the interview were categorised and analysed into themes.

\section{Results}

The data collected from the questionnaire is presented and discussed in three sections. The first section presents the teachers' background. Next, their perceptions on their skills and knowledge a well as the factors affected the implementation of DLP in the urban schools are discussed. 


\subsection{Teachers' Background Information}

The first section discusses on demographic data. The respondents' profile that discuss in this section are gender, age, academic qualification, specialisation, teaching experience, English Language proficiency and experience in teaching PPSMI and courses attended.

Table 1. Background Information

\begin{tabular}{|c|c|c|}
\hline \multicolumn{2}{|c|}{ Background } & \multirow{2}{*}{$\begin{array}{c}\text { Frequency }(\%) \\
4(18.2)\end{array}$} \\
\hline & Male & \\
\hline Gender & Female & $18(81.8)$ \\
\hline \multirow{6}{*}{ Age } & 25 to 30 years old & $10(45.5)$ \\
\hline & 31 to 35 years old & $2(9.1)$ \\
\hline & 36 to 40 years old & $5(22.7)$ \\
\hline & 41 to 45 years old & $2(9.1)$ \\
\hline & 46 to 50 years old & $1(4.5)$ \\
\hline & 51 to 55 years old & $2(9.1)$ \\
\hline Academic qualification & Bachelor Degree & $22(100)$ \\
\hline \multirow{4}{*}{ Specialisation } & English & $3(13.6)$ \\
\hline & Mathematics & $11(50)$ \\
\hline & Science & $7(31.8)$ \\
\hline & Other & $1(4.5)$ \\
\hline \multirow{3}{*}{ Proficiency } & Moderate & $9(40.9)$ \\
\hline & Good & $8(36.4)$ \\
\hline & Very Good & $5(22.7)$ \\
\hline \multirow{4}{*}{ Teaching experience } & Less than 5 year & $7(31.8)$ \\
\hline & 6 to 10 years & $2(9.1)$ \\
\hline & 11 to 15 years & $2(9.1)$ \\
\hline & More than 15 years & $10(45.5)$ \\
\hline \multirow{2}{*}{ Experience in teaching PPSMI } & Yes & $10(45.5)$ \\
\hline & No & $12(54.5)$ \\
\hline \multirow{4}{*}{ Courses attended } & PPSMI course & $10(45.5)$ \\
\hline & Non PPSMI course & $12(54.5)$ \\
\hline & DLP course & $4(18.2)$ \\
\hline & Non DLP course & $18(81.8)$ \\
\hline
\end{tabular}

$\mathrm{n}=22$

Table 1 shows the information of the respondents in term of their gender. There were 18 female teachers $(81.8 \%)$ and 4 male teachers $(18.2 \%)$, which indicated that there are more female teachers than male teachers teaching Mathematics and Science in DLP classes. Majority of the respondents' age are 25-30 years old which are 10 teachers $(45.5 \%)$. Besides that, all the respondents for this study has Bachelor degree for their major. $45.5 \%$ of the teachers had the experience teaching Mathematics and Science in English during PPSMI and had attended the PPSMI course. However, only $4(18.2 \%)$ out of 22 teachers had attended the DLP course since the implementation of DLP in the schools.

\subsection{Teachers' Perceptions on Their Skills and Knowledge}

In this section, there are 23 items that the respondents require to answer on 5 Likert scale to measure on their skills and knowledge in implementing DLP. The scale ranges from strongly disagree (SD), Disagree (D), Neither Agree or Disagree (NAD), Agree (A) and Strongly Agree (SA). Table 2 shows the teachers' perceptions on their skills and knowledge in implementing the dual language programme.

As shown in Table 2, 15 teachers agreed (5 teachers (22.7\%) strongly agreed and 10 (45.5\%) teachers agreed) to the notion that they are proficient in English. The findings also showed that majority of the teachers agreed that they are trying to improve their English proficiency which may help them to implement the DLP successfully.14 (63.6\%) teachers also agreed that they are confident to implement DLP in class. As for statements teachers able to write instructions and construct test items, majority of the teacher agreed that they have the skills to write the instructions and construct test items. $18(81.8 \%)$ teachers also agreed $(15(68.2 \%)$ agreed and $3(13.6 \%)$ strongly agreed) to the statement of they able to guide the pupils to use English in the DLP class and able to achieve the objective of the lesson. 
Table 2. Teachers' Skills

\begin{tabular}{|c|c|c|c|c|c|}
\hline Items & $\begin{array}{l}\text { SD } \\
(\%)\end{array}$ & $\begin{array}{c}\mathrm{D} \\
(\%)\end{array}$ & $\begin{array}{c}\text { NAD } \\
(\%)\end{array}$ & $\begin{array}{c}\text { A } \\
(\%)\end{array}$ & $\begin{array}{l}\text { SA } \\
(\%)\end{array}$ \\
\hline I am proficient in English. & - & $\begin{array}{c}1 \\
(4.5)\end{array}$ & $\begin{array}{c}6 \\
(27.3)\end{array}$ & $\begin{array}{c}10 \\
(45.5)\end{array}$ & $\begin{array}{c}5 \\
(22.7)\end{array}$ \\
\hline I make an effort to improve my English proficiency. & - & - & $\begin{array}{c}3 \\
(13.6)\end{array}$ & $\begin{array}{c}19 \\
(86.4)\end{array}$ & - \\
\hline I am ready to teach Mathematics/Science in English. & - & $\begin{array}{c}5 \\
(22.7)\end{array}$ & $\begin{array}{c}3 \\
(13.6)\end{array}$ & $\begin{array}{c}12 \\
(54.5)\end{array}$ & $\begin{array}{c}2 \\
(9 \%)\end{array}$ \\
\hline I am confident to teach Mathematics/Science in English. & - & $\begin{array}{c}5 \\
(22.7)\end{array}$ & $\begin{array}{c}3 \\
(13.6)\end{array}$ & $\begin{array}{c}12 \\
(54.5)\end{array}$ & $\begin{array}{c}2 \\
(9 \%)\end{array}$ \\
\hline $\begin{array}{l}\text { I am able to use and develop materials for language teaching and learning in } \\
\text { Mathematics/Science. }\end{array}$ & - & $\begin{array}{c}1 \\
(4.5)\end{array}$ & $\begin{array}{c}5 \\
(22.7)\end{array}$ & $\begin{array}{c}13 \\
(59.1)\end{array}$ & $\begin{array}{c}3 \\
(13.6)\end{array}$ \\
\hline I am able to plan lessons in English to teach Mathematics / Science. & - & $\begin{array}{c}2 \\
(9.1)\end{array}$ & $\begin{array}{c}5 \\
(22.7)\end{array}$ & $\begin{array}{c}13 \\
(59.1)\end{array}$ & $\begin{array}{c}2 \\
(9 \%)\end{array}$ \\
\hline $\begin{array}{l}\text { I am able to carry out strategies for language teaching and learning in } \\
\text { Mathematics/Science. }\end{array}$ & - & $\begin{array}{c}4 \\
(18.2)\end{array}$ & $\begin{array}{c}7 \\
(31.8)\end{array}$ & $\begin{array}{c}11 \\
(50)\end{array}$ & - \\
\hline I am able to understand Mathematics/Science reading materials in English. & - & - & $\begin{array}{c}3 \\
(13.6)\end{array}$ & $\begin{array}{c}16 \\
(72.7)\end{array}$ & $\begin{array}{c}3 \\
(13.6)\end{array}$ \\
\hline I am able to write Mathematics/Science instructional materials in English. & - & - & $\begin{array}{c}3 \\
(13.6)\end{array}$ & $\begin{array}{c}16 \\
(72.7)\end{array}$ & $\begin{array}{c}3 \\
(13.6)\end{array}$ \\
\hline I am able to construct test items in English. & - & $\begin{array}{c}2 \\
(9.1)\end{array}$ & $\begin{array}{c}4 \\
(18.2)\end{array}$ & $\begin{array}{c}14 \\
(63.6)\end{array}$ & $\begin{array}{c}2 \\
(9 \%)\end{array}$ \\
\hline I am able to deliver instruction of Mathematics / Science in English. & - & $\begin{array}{c}1 \\
(4.5)\end{array}$ & $\begin{array}{c}5 \\
(22.7)\end{array}$ & $\begin{array}{c}14 \\
(63.6)\end{array}$ & $\begin{array}{c}2 \\
(9 \%)\end{array}$ \\
\hline I am able to guide my pupils to use English in learning Mathematics / Science. & - & $\begin{array}{c}1 \\
(4.5)\end{array}$ & $\begin{array}{c}3 \\
(13.6)\end{array}$ & $\begin{array}{c}15 \\
(68.2)\end{array}$ & $\begin{array}{c}3 \\
(13.6)\end{array}$ \\
\hline I am able to enable my pupils to understand my Mathematics / Science teaching. & - & $\begin{array}{c}1 \\
(4.5)\end{array}$ & $\begin{array}{c}3 \\
(13.6)\end{array}$ & $\begin{array}{c}15 \\
(68.2)\end{array}$ & $\begin{array}{c}3 \\
(13.6)\end{array}$ \\
\hline $\begin{array}{l}\text { I am able to ensure the Mathematics / Science instructional objectives are } \\
\text { achieved. }\end{array}$ & - & $\begin{array}{c}1 \\
(4.5)\end{array}$ & $\begin{array}{c}3 \\
(13.6)\end{array}$ & $\begin{array}{c}15 \\
(68.2)\end{array}$ & $\begin{array}{c}3 \\
(13.6)\end{array}$ \\
\hline I am able to pose questions to pupils in English. & - & - & $\begin{array}{c}2 \\
(9.1)\end{array}$ & $\begin{array}{c}18 \\
(81.8)\end{array}$ & $\begin{array}{c}2 \\
(9.1)\end{array}$ \\
\hline $\begin{array}{l}\text { I am able to handle learning problems of pupils who are weak in Mathematic / } \\
\text { Science to learn Mathematics / Science in English. }\end{array}$ & - & $\begin{array}{c}2 \\
(9.1)\end{array}$ & $\begin{array}{c}5 \\
(22.7)\end{array}$ & $\begin{array}{c}14 \\
(63.6)\end{array}$ & $\begin{array}{c}1 \\
(4.5)\end{array}$ \\
\hline $\begin{array}{l}\text { I am able to handle learning problems of pupils who are weak in English to learn } \\
\text { Mathematics / Science in English. }\end{array}$ & - & $\begin{array}{c}1 \\
(4.5)\end{array}$ & $\begin{array}{c}4 \\
(18.2)\end{array}$ & $\begin{array}{c}17 \\
(77.3)\end{array}$ & - \\
\hline
\end{tabular}

$\mathrm{n}=22$

Table 3. Teachers' Knowledge

\begin{tabular}{|c|c|c|c|c|c|}
\hline Items & $\begin{array}{l}\text { SD } \\
(\%)\end{array}$ & $\begin{array}{c}\mathrm{D} \\
(\%)\end{array}$ & $\begin{array}{c}\text { NAD } \\
(\%)\end{array}$ & $\begin{array}{c}\mathrm{A} \\
(\%)\end{array}$ & $\begin{array}{l}\text { SA } \\
(\%)\end{array}$ \\
\hline The courses I have attended help me in my teaching. & - & $\begin{array}{c}2 \\
(9.1)\end{array}$ & $\begin{array}{c}3 \\
(13.6)\end{array}$ & $\begin{array}{c}16 \\
(72.7)\end{array}$ & $\begin{array}{c}1 \\
(4.5)\end{array}$ \\
\hline I am able to answer pupils' questions in English. & - & - & $\begin{array}{c}2 \\
(9.1)\end{array}$ & $\begin{array}{c}20 \\
(90.9)\end{array}$ & - \\
\hline I always discuss with other teachers to improve my teaching. & - & - & $\begin{array}{c}1 \\
(4.5)\end{array}$ & $\begin{array}{c}17 \\
(77.3)\end{array}$ & $\begin{array}{c}4 \\
(18.2)\end{array}$ \\
\hline I am ready to collaborate with other teachers to successfully implement DLP. & - & - & $\begin{array}{c}3 \\
(13.6)\end{array}$ & $\begin{array}{c}18 \\
(81.8)\end{array}$ & $\begin{array}{c}1 \\
(4.5)\end{array}$ \\
\hline $\begin{array}{l}\text { I am ready to attend courses/workshops organised by PPD/JPN/KPM to improve } \\
\text { my skills or knowledge related to DLP. }\end{array}$ & - & - & - & $\begin{array}{c}6 \\
(27.3)\end{array}$ & $\begin{array}{c}16 \\
(72.7)\end{array}$ \\
\hline
\end{tabular}

$\mathrm{n}=22$ 
The findings indicated that $6(27.3 \%)$ teachers agreed and $16(72.7 \%)$ teachers strongly agreed that they are ready to attend course or workshop on the implementation of this programme. Besides that, the 17 (77.3\%) teachers state that the courses that they attend benefit them in their teaching session. Majority of the teacher agreed that they always discuss and collaborate with other teachers to improve their teaching Mathematics and Science in English.

\subsection{Factors Affecting the Implementation of DLP}

Respondents were also required to choose from a list of challenges that affects the implementation of DLP. Table 4 presents teachers' choices on the challenges.

Table 4. Factors Affecting the Implementation of DLP

\begin{tabular}{ccc}
\hline Challenges & Frequency & $\%$ \\
\hline Not enough time & 4 & 18.1 \\
Facilities/materials/resources & 8 & 36.4 \\
Not enough support/incentive from government & 3 & 13.6 \\
Students' ability & 2 & 9.1 \\
Parents' encouragement & 2 & 9.1 \\
Teachers' lack of skills to teach & 2 & 9.1 \\
Teachers' lack of confidence to teach & 1 & 4.5 \\
\hline
\end{tabular}

$\mathrm{n}=22$

The findings revealed that factors on facilities, materials and resources were mostly chosen as the factor that affects the implementation of DLP with $36.4 \%$. The second factor was on not enough time with $18.1 \%$ followed by not enough support or incentive from the government with $13.6 \%$.

At the end of the survey, the respondents were required to respond to an open-ended question asking for their suggestion on improving DLP. Majority of the teachers felt that factor in term of facilities, materials and resources are vital in order to make this programme a success. Some stated that:

\section{"Improve the teaching resources" teacher A and teacher E}

"Stop burden teacher with unclear programme without proper planning" teacher $B$.

"Attend course on teaching and learning of DLP" teacher $C$.

"Provide enough resources and materials" teacher $D$ and teacher $F$.

All 6 teachers agreed that the programme should be improved in certain areas. Teacher A and Teacher E suggested "Provide enough teaching resources and materials to the teacher". As for Teacher B, "Stop burden teachers with unclear programme and have proper planning first." Teacher C suggested "Please conduct courses on teaching approach and strategy on how to teach Maths and Science in English especially for the new teacher like me." Teacher D and Teacher F suggested "Provide enough teaching resources and materials to the teacher". It shows that all the teacher agreed on make improvement in the teaching resources, materials and also courses as to help them to implement the teaching Mathematics and Science in the class.

\section{Discussion}

English plays an important role as a second language in many countries. A very good command in English is seen as the most important element in getting place in higher education and good job. It is supported from study done by Tuah and Mohini (2010). Besides, Science and Mathematics also very crucial towards moving in this globalisation era as the world is moving towards the world of information and technology (Sidin, 1998). Hence, it is crucial to acquire the English because English is considered as the international language and the language of knowledge. Therefore the implementation of DLP is in line with the development in the world and all the changes happen in the curriculum policy is determined by the needs, God, self, society and knowledge.

There are two major findings that can be concluded for this study. First, the finding reveals the teachers' skills and knowledge that determines their readiness in implementing the DLP. The results show than most of the teachers which is about $15(68.2 \%)$ teachers out of 22 teachers take part in this study are proficient in English. 
This is because the teachers had experience in teaching Mathematics and Science during the PPSMI. Besides that, the teachers also have high education background that they were required to use the language in their Bachelor education. Although there are $5(22.7 \%)$ teacher perceive that they are not proficient but the teachers are ready to improve their proficiency level. Hence, the teachers will not facing any difficulties in delivering the knowledge to the pupils in implementing the DLP in class. The success of the programme is determined by the readiness and competency of the teachers as the teachers play important role in the teaching and learning of Mathematics and Science. This is one of the weaknesses during the implementation of PPSMI as shown in the study done by Julianus (2007) but from this study the teachers find that the language and their skills are not the challenges in the implementation of DLP.

Throughout the research findings, most of the teachers have not attended the DLP course. There are only 4 teachers $(18.2 \%)$ have attended the DLP courses done by the ministry. The teachers were only provided with the curriculum standard and a letter about the implementation of DLP. Therefore, the teachers are not confident and not ready to implement the DLP in the class. This is because the implementation of DLP is different from the implementation of PPSMI. Teachers are the implementers and play an important role in making a programme success. Gunal \& Engin-Demir (2012) also agreed that the teacher need guidance and proper guidelines of the new curriculum and should not left with nothing but knowledge. Through the collaboration and cooperation among the Mathematics and Science teachers managed to overcome this challenge. According to Idris et al (2006) and Ong \& Tan (2008), buddy support among the teachers helped the teachers to teach confidently. This is based on the study done during the implementation of PPSMI. Besides, the teachers are also ready to go for DLP course to increase their level of readiness to teach Mathematics and Science in English as they will have a better view of what the learning contents are.

Other than that, the findings show that the teachers are not equipped with enough resources and facilities to implement the teaching Mathematics and Science in English in the class. Most of the teachers used teaching aids and materials from the previous PPSMI. The ministry and the schools did not provide appropriate resources for the teachers to conduct the lesson in the DLP class. This is because the content during PPSMI did not suit with the current syllabus. Providing suitable and enough materials and references helped the stakeholders to achieve the objective of the programme (Bujang \& Mohd Hamzah, 2016). Due to this challenge, the teachers in the urban schools have utilise the technology provided by the ministry to prepare the teaching aids and materials that suit with the lesson for the pupils.

\section{Conclusion}

The successfulness of dual language programme in Malaysia is determined by several factors such as the readiness of the teachers, the competency of the teachers and the resources provided to teachers. The stakeholders should work together and provide the teachers with all the appropriate needs in implementing the programme and to make it successful unlike the previous PPSMI. The successful implementation of DLP benefits the pupils specifically and the country generally. The ministry and other stakeholders should review some challenges faced by the teachers during the implementation of DLP and make some improvement to the programme. Current teaching aids and materials should be provided align with the current syllabus and the needs of $21^{\text {st }}$ century learning as we can achieve the objective of the programme and the national education aspirations as stated in the Malaysian Education Blueprint 2013 - 2015.

\section{References}

Collier, V. P., \& Thomas, W. P. (2004). The Astounding Effectiveness of Dual Language Education for All. NABE Journal of Research and Practice, 2(1), 1-20.

Gunal, O. D., \& Engin-Demir, C. (2012). Implementation of the new eighth grade English language curriculum from the perspectives of teachers and students. Procedia Social and Behavioral Sciences, 47, 1002-1006. https://doi.org/10.1016/j.sbspro.2012.06.769

Hamidah, A. R., Aziz, N., Mukheta, I., Fatimah, P., Faruk, M., Norazam, A. M., Aminah, A. K., \& Zurihahmi, Z. (2005, November). Teachers' competency in the teaching of mathematics in English in Malaysian secondary schools. Proceedings of the Eighth International Conference Reform, Revolution and Paradigm Shifts in Mathematics Education, Johor Bahru.

Haron, I., Gapor, L., Masran, M., N., Ibrahim, A., H., \& Nor, M. M. (2008). Kesan dasar Pengajaran Matematik dan Sains dalam Bahasa Inggeris. Retrieved from http://www.scribd.com/doc/11492280/PPSMI-Kajian-UPSI-April-2008-Penuh.

Idris, N., Loh, S. C., Razak, A. Z. A., Nor, N. M., \& Saad, R. M. (2006). Effective Implementation of Teaching 
Mathematics and Science in English: A Case Study. Jurnal Pendidikan, 26, 101-115.

Ishak, T., \& Mohamed, M. (2010). Pengajaran dan Pembelajaran Sains dan Matematik dalam Bahasa Inggeris (PPSMI): Suatu Isu Berulang. Jurnal Teknologi, 53, 95-106. https://doi.org/10.11113/jt.v53.116

Jalaluddin, N. H. (2009). Why PPSMI Reversal Makes Sense. Retrieved from http://www.scribd.com/doc/17504214/Why-PPSMI-Reversal-Makes-Sense

Julianus Anggau. (2007). Masalah dan Cabaran Pelaksanaan dan Pengajaran Sains dan Matematik dalam Bahasa Inggeris di sebuah Sekolah Menengah Pedalaman Daerah Ranau. Masters Dissertation. Universiti Malaya

Kamlun, K. (2005). Teachers' Perceptions of Their Level Readiness in Teaching Mathematics and Science in English (eTEMS) (Master thesis, Universiti Kebangsaan Malaysia, Bangi).

Lindholm-Leary, K. (2016). Students' Perceptions of Bilingualism in Spanish and Mandarin Dual Language

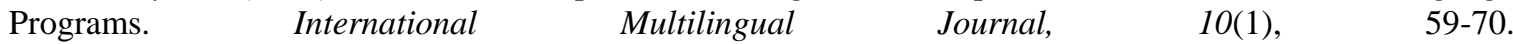
https://doi.org/10.1080/19313152.2016.1118671

Lindholm-Leary, K. J. (2001). Dual Language Education. Avon, England: Multilingual Matters. https://doi.org/10.21832/9781853595332

Malaysian Digest. (2016). Malaysians Need The Dual Language Programme To Enhance English Proficiency In Schools, Experts Say. Retrieved from http://malaysiandigest.com/frontpage/282-main-tile/637949-malaysians-need-the-dual-language-programm e-to-enhance-english-proficiency-in-schools-experts-say.html.

Menon, S. (2016). 841 schools expected to implement DLP. The Star. Retrieved from http://www.thestar.com.my/news/nation/2016/10/06/841-schools-expected-to-implement-dlp/.

Ministry of Education. (2013). Malaysia Education Blueprint 2013-2025. Putrajaya.

Mohandas, P., \& Rajaratnam, P. O. C. (2015). A policy analysis of the delivery of primary and secondary school Mathematics and Science in English. Education Research and Perspectives, 4, 246-285.

Ong, S. L., \& Tan, M. (2008). Mathematics and Science in English:Teachers Experience Inside The Classroom. Jurnal Pendidik dan Pendidikan, Jilid 23, 141-150.

Piaw, C. Y. (2016). Mastering Research Methods (2nd ed.). Shah Alam: Mc Graw Hill Education.

Sidin, R. (1998). Pemikiran dalam Pendidikan. Shah Alam: Fajar Bakti.

The Star. (2017). 12 November. Success with the DLP. Retrieved from https://www.thestar.com.my/news/education/2017/11/12/success-with-the-dlp/.

Thirusanku, J., \& Melor, M. Y. (2012). The many faces of Malaysian English. International Scholarly Research Network. https://doi.org/10.5402/2012/138982

Thomas, W. P., \& Collier, V. P. (2011). Drs. Thomas And Collier Share The Educational Implications Of Their Research On Dual Language Programs. ESL Globe, 8(1), 1-2. Raleigh, NC: North Carolina State University.

Yunus, M. M., \& Sukri, S. I. A. (2017). The Use of English in Teaching Mathematics and Science: The PPSMI Policy vis-a-vis The DLP. Advances in Language and Literary Studies, 8(1), 133-142. https://doi.org/10.7575/aiac.alls.v.8n.1p.133

\section{Copyrights}

Copyright for this article is retained by the author(s), with first publication rights granted to the journal.

This is an open-access article distributed under the terms and conditions of the Creative Commons Attribution license (http://creativecommons.org/licenses/by/4.0/). 